\title{
WHERE TO DRAW THE LINE?: JUDICIAL REVIEW OF POLITICAL GERRYMANDERS
}

\author{
SAMUEL ISSACHAROFF ${ }^{\dagger}$ \\ PAMELA S. KARLAN ${ }^{H}$
}

Chief Justice Warren called Reynolds $v$. Sims ${ }^{1}$ his most important opinion "because it insured that henceforth elections would reflect the collective public interest-embodied in the 'one-man, onevote' standard-rather than the machinations of special interests." The Supreme Court marked Reynolds' fortieth anniversary with a pair of decisions that reveal a central fact about contemporary redistricting: whatever else Reynolds has accomplished, the machinations of special interests in the electoral process are as dominant as ever. In Vieth v. Jubelirer, ${ }^{3}$ the Court confronted a blatant Republican gerrymander of Pennsylvania's congressional delegation; in Cox v. Larios, ${ }^{4}$ the Court reviewed an equally shameless effort to preordain Democratic dominance of Georgia's state legislature.

What's striking about the post-2000 redistricting cases ${ }^{5}$ is not only

\footnotetext{
${ }^{\dagger}$ Harold R. Medina Professor in Procedural Jurisprudence, Columbia Law School.

${ }^{+\dagger}$ Kenneth and Harle Montgomery Professor of Public Interest Law, Stanford Law School.

Many of the ideas in this piece grew out of conversations with our longtime coauthor Rick Pildes and with Dan Ortiz. Adam Orford and Karin Johnsrud provided indispensable research assistance.

${ }^{1} 377$ U.S. 533 (1964).

2 G. EDWARD WHITE, EARL WARREN: A PUBLIC LifE 337 (1982).

3 124 S. Ct. 1769 (2004).

124 S. Ct. 2806 (2004).

${ }^{5}$ In addition to Vieth and Larios, other Supreme Court decisions regarding the post-2000 redistricting include Jackson v. Perry, 125 S.Ct. __ (2004) (Oct. 18, 2004) (Nos. 03-1391, 03-1396, 03-1399, 03-1300, 03- 9644) (vacating and remanding for reconsideration in light of Vieth, a set of appeals from Texas's decision, after Republicans gained control over both houses of the state legislature as well as the governorship, to re-redistrict congressional district boundaries in mid-decade); Colorado General Assembly v. Salazar, 124 S. Ct. 2228 (2004) (refusing to hear, over three Justices' dissent, the decision of the Colorado Supreme Court to strike down the state legislature's attempt to redistrict the state's congressional districts a second time); Georgia v. Ashcroft, 123 S. Ct. 2498 (2003) (reversing a decision refusing to approve Georgia's state senate redistricting); and O'Lear $v$. Miller, 537 U.S. 997 (2002) (affirming the dismissal of a political gerrymandering challenge to Michigan's congressional redistricting). Still on the Court's docket is an appeal involving a Republican-inspired map for the New York state senate that systematically underpopulated upstate, overwhelmingly white Republican
} 
the continued-indeed, ever-increasing-vigor of partisan line drawing, but the array of doctrinal tools litigators and courts have invoked in attempts to rein it in: Article I, Sections 2 and 4 of the Constitution; the First Amendment; the Equal Protection Clause of the Fourteenth Amendment in a range of flavors- the one person, one vote rules of Reynolds and Wesberry v. Sanders, ${ }^{6}$ the race-can't-be-the-predominant-factor principle of Shaw v. Reno ${ }^{7}$ and Miller v. Johnson, ${ }^{8}$ the consistent-degradationof-voter-influence-on-the-political-process-as-a-whole standard of Davis v. Bandemer, ${ }^{9}$ and a slew of new tests for judging political gerrymandering; sections 2 and 5 of the Voting Rights Act of $1965 ;{ }^{10}$ and a variety of state-law principles. ${ }^{11}$

This essay offers a preliminary reaction to the Court's decisions in Vieth and Larios, and places the unclear doctrinal foundations of those cases in the broader context of the Court's failure to confront ends-oriented redistricting practices. In Vieth, four Justices took the position that claims of excessive partisanship in the redistricting process should be nonjusticiable. And yet, barely two months later, three of those Justices were part of an eight-Justice majority that affirmed the judgment in Larios, a case in which the lower court struck down a plan on the grounds that relatively minuscule population deviations were constitutionally impermissible because they reflected "blatantly partisan and discriminatory" attempts to protect Democratic incumbents while undermining Republican-held seats. ${ }^{12}$ As Sister Maria

districts and overpopulated downstate Democratic districts. Rodriguez v. Pataki, 308 F Supp. 2d 346 (S.D.N.Y. 2004), appeal docketed, No. 04-218 (U.S. Aug. 17, 2004).

376 U.S. 1 (1964).

${ }^{7} 509$ U.S. 630 (1993).

8 515 U.S. 900 (1995).

${ }^{9} 478$ U.S. 109 (1986).

${ }^{10}$ Voting Rights Act of 1965, Pub. L. No. 89-110, §§ 2, 5, 79 Stat. 437, 437, 439 (1965) (codified as amended at 42 U.S.C. $\$ \S 1973,1733 c(2000)$ ).

${ }^{11}$ For example, in People ex rel. Salazar v. Davidson, 79 P.3d 1221 (Colo. 2003) (en banc), cert. denied sub nom. Colorado General Assembly v. Salazar, 124 S. Ct. 2228 (2004), the plaintiff successfully claimed that the Colorado legislature's attempt to redraw the state's congressional districts violated the state redistricting provision, COLO. CONST. art. V, $\S 44$, which the Colorado Supreme Court construed to permit only one decennial reapportionment. In Wilkins v. West, 571 S.E.2d 100 (Va. 2002), the plaintiffs unsuccessfully invoked the state constitutional requirements of compactness and contiguity, VA. CONST. art. II, $\S 6$, and the prohibition on racial discrimination, $i d$. art. I, $\S 11$, to attack what they alleged was an unconstitutional gerrymander. And in Pennsylvania itself, a first group of plaintiffs challenged the plan involved in Vieth as a violation of the state constitution's equal protection guarantees, PA. CONST. art. 1, $\S \S 1,26$, and the free and equal elections clause, $i d . \S 5$. Erfer v. Commonwealth, 794 A.2d 325 (Pa. 2002).

${ }^{12}$ Larios v. Cox, 300 F. Supp. 2d 1320, 1347 (N.D. Ga.) (per curiam) (three-judge 
says in The Sound of Music, "When the Lord closes a door, somewhere He opens a window." ${ }^{13}$

Our central claims are twofold. First, no matter how difficult judicial review of political gerrymandering claims may be-and the fact that the Vieth Court offered at least four new standards for assessing them suggests the lack of any clear consensus-the overall doctrinal structure governing redistricting makes it impossible actually to render such claims nonjusticiable. A first law of political thermodynamics guarantees that partisan challenges cannot be eliminated; at most, they can be channeled into different doctrinal pigeonholes. Given the gains to be had from controlling the districting process, and given the number of doctrinal vehicles, a significant number of the partisan gerrymanders that courts find constitutionally offensive-whatever that term in fact means, and whether it even has any agreed-upon meaning-will lead to judicial intervention, and the lack of candor about what courts are doing may carry its own costs.

Second, the treatment of political gerrymander cases as a species of antidiscrimination claim obscures a central issue of democratic theory. Partisan gerrymandering claims rest on an assertion that a political party has been unfairly denied some number of seats. But given the near-universal use in the United States of single-member districts to select legislative bodies and the near-universal practice of incumbent protection in the redistricting process, partisan gerrymandering claims do nothing to make individual elections more competitive or to give individual voters greater choice among candidates; they seek primarily to redistribute the allocation of safe seats. The Justices' recent opinions almost entirely ignore the question whether judicial intervention should be directed at entrenchment itself, rather than the secondary question of who gets to be entrenched. In fact, to the extent that the Court's intervention is prompted by claims of excessive partisanship, it may actually encourage further reductions in political competition.

\section{THE JUDiCIAL THICKET}

When Justice Felix Frankfurter warned his colleagues that "courts ought not to enter [the] political thicket" of redistricting, ${ }^{14}$ he could not have foreseen that within a half-century, the Court would create a

\footnotetext{
court), aff'd, 124 S. Ct. 2806 (2004).

${ }^{13}$ The Sound OF Music (Twentieth Century Fox 1965).

${ }^{14}$ Colegrove v. Green, 328 U.S. 549, 556 (1946) (Frankfurter, J., plurality opinion).
} 
judicial thicket of overlapping and often cross-cutting constitutional constraints on the redistricting process. The post-2000 process, like each of the decennial processes that have taken place since Baker $v$. Carr $^{15}$ announced the justiciability of challenges to apportionment schemes, occurred under a legal regime whose contours were still under construction. The Court's inability to create a stable set of rules reflects several factors: the changing technology of the redistricting process itself; changes in political dynamics within individual states; and changes and uncertainty about fundamental questions of representation and political fairness.

The central vice presented by the first round of cases the Court confronted during the "Reapportionment Revolution" was minority entrenchment. Many states had last redrawn state legislative boundaries at the turn of the twentieth century, and their legislatures had become backwater relics of past political deals, controlled by lawmakers from rural hamlets in decline whose reactionary politics stymied the interests of voters in the burgeoning cities and suburbs. And even with respect to congressional districts-where apportionment meant that the size of many states' congressional delegations changed from decade to decade, thereby requiring at least some reconsideration of district boundaries-rural-dominated state legislatures would draw congressional districts that disproportionately favored rural areas. Urban districts generally contained far larger populations than their rural counterparts. ${ }^{16}$

The Court's solution was a requirement of equipopulous districting expressed in terms of individual rights: one person, one vote. ${ }^{17}$

${ }^{15} 369$ U.S. 186 (1962).

${ }^{16}$ See Anthony Lewis, Legislative Apportionment and the Federal Courts, 71 HARV. L. REV. 1057, 1065-66 \& n.44 (1958) (discussing an "important secondary effect" of malapportionment-that "cities turn to [the federal government]" for solutions because state legislatures "ignore urban needs," and quoting Senator Paul Douglas about the irony of "those who complain most about Federal encroachment in the affairs of the States" being the ones who deny "urban majorities" the ability to use the state's machinery to address their problems).

${ }^{17}$ As we have explained elsewhere, one person, one vote's individualistic rhetoric may have come to obscure its original purposes of combating entrenchment and safeguarding majority rule. Lani Guinier \& Pamela S. Karlan, The Majoritarian Difficulty: One Person, One Vote, in REASOn AND PASSION: Justice Brennan's ENDURING INFLUENCE 207, 207-22 (E. Joshua Rosenkranz \& Bernard Schwartz eds., 1997); see also Michael W. McConnell, The Redistricting Cases: Original Mistakes and Current Consequences, 24 HARV. J.L. \& PUB. POL'Y 103, 114 (2000) (arguing that the Republican Form of Government Clause of Article IV would have provided a better doctrinal basis for the Reapportionment Revolution since it would have focused attention on structural issues involving allocation of power among groups). 
With respect to congressional plans, that requirement was located doctrinally within Article I, Section 2's requirement that members of the House of Representatives be chosen "by the People of the several States." ${ }^{\prime 18}$ In a series of cases culminating with its 1983 decision in Karcher v. Daggett, ${ }^{19}$ the Court construed the Article I strand of one person, one vote to reject any de minimis exception to the principle of absolute population equality among districts. States were required to justify any avoidable population deviation by showing that the deviation was necessary to the achievement of some "legitimate" and "nondiscriminatory" objective. ${ }^{20}$ With respect to state legislative plans, the requirement of one person, one vote was located doctrinally within the Equal Protection Clause. ${ }^{21}$ Here, the Court held that " $[\mathrm{m}]$ inor deviations from mathematical equality among state legislative districts are insufficient to make out a prima facie case of invidious discrimination under the Fourteenth Amendment so as to require justification by the State." ${ }^{22}$ A series of cases seemed to establish the proposition that "as a general matter, ... an apportionment plan with a maximum population deviation under $10 \%$ falls within this category of minor deviations." ${ }^{23}$

In practical terms, the primary effect of one person, one vote has been to require states to revisit district boundaries after every census. But that revisitation, by itself, does not necessarily either produce majority control or prevent entrenchment. As Justice Stewart pointed out the day Reynolds was decided, "[e]ven with legislative districts of exactly equal voter population, $26 \%$ of the electorate (a bare majority of the voters in a bare majority of the districts) can, as a matter of the

${ }^{18}$ See Wesberry v. Sanders, 376 U.S. 1, 7-8 (1964) ("We hold that, construed in its historical context, the command of [Article I, Section 2], that Representatives be chosen 'by the People of the several States' means that as nearly as is practicable one man's vote in a congressional election is to be worth as much as another's." (footnote omitted)).

19462 U.S. 725 (1983).

Id. at $739-40$

${ }^{21}$ See Reynolds v. Sims, 377 U.S. 533, 577 (1964) ("By holding that as a federal constitutional requisite both houses of a state legislature must be apportioned on a population basis, we mean that the Equal Protection Cause requires that a State make an honest and good faith effort to construct districts, in both houses of its legislature, as nearly of equal population as is practicable.").

${ }^{22}$ Brown v. Thomson, 462 U.S. 835, 842 (1983) (quoting Gaffney v. Cummings, 412 U.S. 735, 745 (1973)); see also White v. Regester, 412 U.S. 755, 764 (1973) (upholding against a malapportionment claim a plan the Court nonetheless struck down because of its dilution of the voting strength of black and Mexican American voters).

${ }^{23}$ Brown, 462 U.S. at 842. 
kind of theoretical mathematics embraced by the Court, elect a majority of the legislature. ${ }^{24}$ While there have been few if any examples of the limiting case, there are plenty of jurisdictions in which a party manages to obtain a substantial majority of the seats with a minority of the votes. ${ }^{25}$ Precisely because it elevates equality of population over all other criteria, one person, one vote can serve as a smokescreen for politically driven deviations from other districting principles. When it comes to district-level entrenchment, the necessity of tinkering with the lines every ten years can turn into an opportunity to redraw districts to shore up incumbents who otherwise might face defeat. ${ }^{26}$

The Court soon acknowledged the possibility that even if a redistricting plan complied with one person, one vote, "[i]t might well be that, designedly or otherwise," a particular "apportionment scheme, under the circumstances of a particular case, would operate to mini-

${ }^{24}$ Lucas v. Forty-Fourth Gen. Assembly, 377 U.S. 713, 750 n.12 (1964) (Stewart, J., dissenting).

${ }^{25}$ The plans before the Court in Larios, Vieth, and Bandemer are arguably all illustrations of this phenomenon. See Cox v. Larios, 124 S. Ct. 2806, 2808 n.* (2004) (Stevens, J., concurring) (stating that "although Republicans won a majority of votes statewide (991,108 Republican votes to 814,641 Democrat votes), Democrats won a majority of the state senate seats (30 to 26)" in the 2002 elections); Appellants' Reply Brief at 16, Vieth v. Jubelirer, 124 S. Ct. 1769 (2004) (No. 02-1580) (noting that in the November 2000 election, conducted under the prior plan, Democrats had received a majority of the votes for congressional candidates cast statewide; the new plan was designed to give the Republicans at least two-thirds of the seats); Davis v. Bandemer, 478 U.S. 109, 113, 115 (1986) (noting that in the 1982 elections for the Indiana House of Representatives, Democratic candidates received $51.9 \%$ of the vote but won only 43 of 100 seats).

${ }^{26}$ The recent Colorado re-redistricting provides an especially pointed example. Under a 2001 plan drawn by a state court that explicitly attempted to create a competitive district, Colorado's newly acquired Seventh Congressional District elected a Republican in 2002 by only 121 votes out of roughly 170,000 votes cast- "the narrowest margin [of victory] in the nation." See People ex rel. Salazar v. Davidson, 79 P.3d 1221, 1227 (Colo. 2003), cert. denied sub nom. Colo. Gen. Assembly v. Salazar, 124 S. Ct. 2228 (2004). When Republicans gained control over both houses of the state legislature as well as the governorship, they redrew the district's boundaries. The president of the state senate, John Andrews, was candid about the entirely partisan goal. In an op-ed explaining why the legislature was redrawing the boundaries mid-cycle, he wrote: "The Democrats' failure to win [the] seat in 2002 was small comfort. The numbers were going to favor them in time. America is better served by Congress as it is. To help keep it that way, we set our sights on correcting ... [the state court's] map." John Andrews, Editorial, Districts Remapped in Public Interest, Rocky MTN. News, June 9, 2003, at 30A. The new plan took the Seventh District and transformed it into a safe Republican seat by giving Republicans a decisive advantage in registered voters. See Editorial, A Dirty Deed Beneath the Dome, Denver Post, May 6, 2003, at B6 ("The current 7th District . . is almost exactly divided between Democratic, Republican and unaffiliated voters. But [Senator] Andrews wants to give [Republican Representative-elect Bob] Beauprezsoon-to-be Congressman for Life-an overwhelming 141,854 to 113,876 edge.”). 
mize or cancel out the voting strength of racial or political elements of the voting population. ${ }^{27}$ During the 1970s and 1980s, the Court sought to identify the circumstances in which a plan unconstitutionally diluted a group's voting strength.

For present purposes, the salient features of the Court's racial vote dilution cases can be summarized briefly. First, the Court treated partisan politics as an explanatory factor that could defeat a claim of unconstitutional racial vote dilution. In Wright $v$. Rockefeller, ${ }^{28}$ for example, the Court refused to strike down a congressional redistricting plan that divided the east side of Manhattan block by block, creating adjacent districts with dramatically different racial compositions. The best explanation for the jagged line was the desire of upstate Republicans to preserve a traditional Republican seat in a heavily Democratic city, and the district court accused the plaintiffs of trying to "inject a racial angle" into a dispute that actually involved "warring political factions. ${ }^{29}$ Similarly, in Whitcomb v. Chavis, ${ }^{30}$ the Court upheld Indiana's legislative redistricting against a claim of unconstitutional racial vote dilution, finding that the failure of blacks in Indianapolis to elect the candidates of their choice was a function of partisan politics: their political fortunes rose and fell in tandem with the prospects of Democratic voters generally. ${ }^{31}$

By contrast, in White $v$. Regester, ${ }^{32}$ partisan politics could not provide an explanation for minority electoral defeat. The Texas state legislative reapportionment plan "stacked" minority voters, using multimember, majority-white districts in areas where it would have been possible to draw majority-black or majority-Latino single-member districts, and minority candidates were losing out within the Democratic primary. ${ }^{33}$ In retrospect, White $v$. Regester provided not only the evidentiary factors for assessing a claim of impermissible minority exclusion from the po-

${ }^{27}$ Fortson v. Dorsey, 379 U.S. 433, 439 (1965).

${ }^{28} 376$ U.S. 52 (1964).

${ }^{29}$ Wright v. Rockefeller, 211 F. Supp. 460, 464, 466 (S.D.N.Y. 1962) (three-judge court).

403 U.S. 124 (1971).

${ }^{31}$ See id. at 154-55 ("The mere fact that one interest group or another... has found itself outvoted and without legislative seats of its own provides no basis for invoking constitutional remedies where, as here, there is no indication that this segment of the population is being denied access to the political system.").

412 U.S. 755 (1973).

${ }^{33}$ See id. at 765-67 (describing the way in which the districts diluted minority voting strength). 
litical process, ${ }^{34}$ but also the prototypical political setting for minority voting rights claims. The salient feature of virtually all of the early minority vote dilution cases is that they arose in either the one-party Democratic South or in urban areas equally under the sway of a single party. Tacitly, or as in Whitcomb not so tacitly, courts seemed prepared to immunize jurisdictions that provided meaningful bipartisan competition from claims of vote dilution. Thus, the racial vote dilution cases implicitly recognized political considerations as a legitimizing factor in sorting out electoral opportunity.

Second, in contrast to the one person, one vote cases, the racial vote dilution decisions were explicitly nonmajoritarian. They thus required a somewhat more robust theory of democracy to justify judicial intervention. While the Court's rationale contains at least traces of all three of the Carolene Products justifications for heightened judicial scrutiny, ${ }^{35}$ it sounds primarily in the third. Ultimately, the test for unconstitutional racial vote dilution essentially unpacked the phrase "prejudice against discrete and insular minorities ... which tends seriously to curtail the operation of those political processes ordinarily to be relied upon." ${ }^{36}$ The Court required plaintiffs to prove that the challenged plan had both a discriminatory purpose and a discriminatory effect. ${ }^{37}$ The discriminatory purpose requirement, of course, maps directly onto the concept of "prejudice": plaintiffs had to show that officials adopted the challenged plan precisely because of its adverse impact

${ }^{34}$ The factors identified in White $v$. Regester, id. at 766-67, were later set out in the senate report accompanying the 1982 amendments to section 2 of the Voting Rights Act of 1965 as "[t]ypical factors" that served to establish a violation of the Act, which proscribed the use of electoral structures that deny minority voters an equal opportunity to participate in the political process and to elect candidates of their choice. S. REP. No. 97-417, at 28-29 (1982); see also Voting Rights Act Amendments of 1982, Pub. L. No. 97-205, sec. 3, § 2, 96 Stat. 131, 134 (1982) (codified at 42 U.S.C. $§ 1973$ (2000)) (amending section 2).

${ }^{35}$ In United States v. Carolene Products Co., 304 U.S. 144 (1938), the Supreme Court identified three conditions under which the normal presumption of constitutionality should be relaxed: (1) "when legislation appears on its face to be within a specific prohibition of the Constitution"; (2) when the legislation "restricts those political processes which can ordinarily be expected to bring about repeal of undesirable legislation"; and (3) when a statute is "directed ... against discrete and insular minorities" as to whom "prejudice ... may be a special condition, which tends seriously to curtail the operation of those political processes ordinarily to be relied upon to protect minorities." Id. at 152-53 n.4. For a more extensive discussion of vote dilution and its relationship to Carolene Products, see Pamela S. Karlan, John Hart Ely and the Problem of Gerrymandering: the Lion in Winter, 114 YALE L.J. (forthcoming 2005).

${ }^{36}$ Carolene Prods. Co., 304 U.S. at 152-53 n.4 (emphasis added).

${ }^{37}$ See City of Mobile v. Bolden, 446 U.S. 55, 62 (1980) (plurality opinion) (articulating this requirement). 
on a racial minority. The discriminatory effect requirement turned out to rest on the ideas of discreteness and insularity. Although developed mostly in the subconstitutional cases under section 2 of the Voting Rights Act, particularly Thornburg $v$. Gingles, ${ }^{38}$ the logic of the effects prong pushes to the core of the Carolene Products concern. First, the centrality of bloc voting to the dilution inquiry meant that the plaintiffs had to show the minority group was politically cohesive and that its preferences were electorally "discrete" and "insular," that is, distinct from those of the rest of the electorate. Persistent racial bloc voting provided evidence that minority voters were likely to be disabled from using the political process to protect their interests. ${ }^{39}$ Indeed, it raised the question whether nonminority voters were actuated by "prejudice" in refusing to make common cause with minority voters. ${ }^{40}$ Second, plaintiffs had to show that the minority group was geographically "discrete" and "insular," that is, sufficiently large and geographically compact to constitute a majority in a fairly drawn alternative district. ${ }^{41}$ Thus, Carolene Products provided a rationale for explaining the nature of the constitutional injury caused by racial vote dilution and a test for deciding when judicial intervention was warranted.

In 1986, in Davis v. Bandemer, ${ }^{42}$ the Court moved further into the political thicket, holding that claims of unconstitutional partisan ger-

${ }^{38} 478$ U.S. 30 (1986). There, the Court articulated the now canonical threeprong test for proving racial vote dilution:

First, the minority group must be able to demonstrate that it is sufficiently large and geographically compact to constitute a majority in a single-member district. If it is not, as would be the case in a substantially integrated district, the multimember form of the district cannot be responsible for minority voters' inability to elect [their preferred] candidates. Second, the minority group must be able to show that it is politically cohesive. . . Third, the minority must be able to demonstrate that the white majority votes sufficiently as a bloc to enable it ... usually to defeat the minority's preferred candidate.

Id. at 50-51 (footnotes and internal citations omitted). For an extensive discussion of the elaboration of this framework over the ensuing generation, see SAMUEL Issacharoff, Pamela S. Karlan \& Richard H. Pildes, The LaW of Democracy: Legal Structure of the Political Process $769-859$ (rev. 2d ed. 2002).

${ }^{39}$ For a fuller discussion of the relationship between Carolene Products and polarized voting, see Samuel Issacharoff, Polarized Voting and the Political Process: The Transformation of Voting Rights Jurisprudence, 90 MICH. L. REV. 1833, 1865-67, 1886 (1992).

${ }^{40}$ See John Hart Ely, Democracy and Distrust: A Theory of Judicial ReView 103 (1980) (describing Carolene Products prejudice in terms of a refusal of the majority to recognize commonalities of interest).

${ }^{41}$ See Gingles, 478 U.S. at 50 (reasoning that otherwise "the multimember form of the district cannot be responsible for minority voters' inability to elect its candidates").

${ }^{42} 478$ U.S. 109 (1986). 
rymandering were justiciable under the Equal Protection Clause. Decided the same day as Gingles, Bandemer adopted the formal shell that had first been articulated in the racial vote dilution cases: a districting scheme violates the Constitution when it is motivated by an impermissibly discriminatory purpose and has an impermissibly discriminatory effect. But the Court did not adopt the meanings of "purpose" and "effect" that had been articulated in the racial vote dilution cases. In fact, the six Justices who thought claims of unconstitutional political gerrymandering were justiciable could not agree on a test for actually adjudicating such claims. The plurality's test set a high-indeed, insuperable-threshold: the plaintiffs would have to show not only that the plan had been crafted for partisan reasons, but also that it caused a consistent degradation of the plaintiff group's influence on the political process as a whole. ${ }^{43}$ In the ensuing eighteen years, not a single challenge to a congressional or state legislative reapportionment managed to satisfy this standard. Indeed, in Vieth, Justice Scalia would come to quote our account of the history of Bandemer to show that it had "begot only confusion."

The failure of Bandemer was entirely foreseeable for two primary reasons. First, at a more conceptual level, to the extent that the minority vote dilution claims drew their jurisprudential ballast from the rationale of Carolene Products, such an approach was unavailing in the case of partisan discrimination claims advanced by the major political parties. In Vieth, for example, the claim of discrimination was advanced by the Democratic Party, which, by the time the litigation reached the Supreme Court, controlled the Pennsylvania governorship (held by the former chair of the Democratic National Committee, no less) and the mayoralty of the state's two largest cities, Philadelphia and Pittsburgh. It is difficult to transpose to such wellpositioned political actors the concepts of discreteness, insularity, and lack of recourse to the political process, the key operative features of the Carolene Products approach. Whereas Carolene Products sought to define impermissible exclusion, the claims in Vieth appeared to sound not in being outsiders to the political process, but in

${ }^{43}$ See id. at 132 (setting out this standard for determining unconstitutional political gerrymandering).

${ }^{44}$ Vieth v. Jubelirer, 124 S. Ct. 1769, 1780 (2004) (plurality opinion) (quoting Samuel Issacharoff, Judging Politics: The Elusive Quest for Judicial Review of Political Fairness, 71 TEX. L. REv. 1643, 1671 (1993)); see also id. at 1777 ("As one commentary has put it, " $[\mathrm{t}]$ hroughout its subsequent history, Bandemer has served almost exclusively as an invitation to litigation without much prospect of redress."' (quoting IsSACHAROFF, KARLAN \& PILDES, supra note 38, at 886)). 
entitlement to proportionate spoils within a more or less rigged process.

Second, at the level of actual application, given the primary techniques for gerrymandering in the post-Reynolds world-the euphoniously named "cracking" and "packing" - the Bandemer test could never be met. The point of gerrymandering is for the party controlling the process (the "in-party") to distribute its own supporters efficiently - to win as many seats as possible-while wasting the votes of the "out-party." In a system of single-member districts, there are two ways to waste out-party votes. One technique simply submerges outparty adherents in predominantly in-party districts. Sometimes, when out-party supporters live in large geographic concentrations, this requires artful line drawing, in which out-party neighborhoods are carved up- ccracked"-and the pieces attached to larger concentrations of in-party voters. In the abstract, cracking is the more efficient technique, for if the out-party's supporters can be completely cracked, it can be denied any seats at all.

But cracking alone usually is not enough. First, if the two parties have relatively close numbers of adherents, cracking may be politically risky. For example, if the in-party expects to receive $52 \%$ of the vote, at most cracking alone will allow it to create a series of 52-48 districts. Most politicians, however, want decidedly safer districts- that is, districts where they can expect to receive, say, at least $55 \%$ of the vote, or-as we shall see-considerably more. This gives rise to the argument, voiced by Justice O'Connor in Bandemer, that ultimately there is a self-regulating equilibrium that constrains the excesses of partisan land grabs. ${ }^{46}$ Second, there may be legal constraints on the ability to

${ }^{45}$ See id. at $1781 \mathrm{n} .7$ ("'Packing' refers to the practice of filling a district with a supermajority of a given group or party. 'Cracking' involves the splitting of a group or party among several districts to deny that group or party a majority in any of those districts."). For a discussion of these two, plus their third rhyming cousin-"stacking," which involves the use of multimember districts-see Pamela S. Karlan, All Over the Map: The Supreme Court's Voting Rights Trilogy, 1993 SuP. CT. REv. 245, 250 (1993).

${ }^{46}$ Justice O'Connor argued in Bandemer for the nonjusticiability of political gerrymandering claims in part on the grounds that political gerrymandering is a selflimiting enterprise, because

[i]n order to gerrymander, the legislative majority must weaken some of its safe seats, thus exposing its own incumbents to greater risks of defeat.... Similarly, an overambitious gerrymander can lead to disaster for the legislative majority: because it has created more seats in which it hopes to win relatively narrow victories, the same swing in overall voting strength will tend to cost the legislative majority more and more seats as the gerrymander becomes more ambitious.

478 U.S. at 152 (O’Connor, J., concurring in the judgment). 
crack: section 2 of the Voting Rights Act, for example, makes it legally risky for a jurisdiction to crack a geographically compact, politically cohesive minority community and submerge the fragments in majority-white districts. Finally, even after forty years of vigorous gerrymandering, there is still some residual normative force to the idea that districts should reflect some reality on the ground, or at least there had been until lately.

This is where packing comes in. Packing wastes the other party's votes by giving them landslide victories in a relatively few number of districts- "packing" those districts with supporters of the out-partythereby leaving the remaining districts easier for the in-party to control. Packing relegates the out-party to fewer-often far fewer-seats than its share of the overall vote might be thought to warrant. But packing by definition concedes some seats to the out-party. So the out-party is not excluded from the legislature entirely. If that is the proof Bandemer requires, it will never be met, at least not with respect to a major political party. Packing also has the side benefit of inducing (or seducing) at least some incumbent elected officials of the opposing party to join in the gerrymandering effort. What incumbent would not love to run for office in a district overwhelmingly populated by partisans of her own party? ? $^{47}$

Contemporary partisan gerrymandering also involves a third technique, which we shall call "shacking": focusing not only on where the other party's supporters live, but also on where its representatives reside. Incumbency gives candidates a significant advantage. Partisan line drawing can dampen this advantage in two ways. First, districts can be redrawn so an incumbent's residence (her "shack") is in a district that no longer contains her current constituents. ${ }^{48}$ This deprives an incumbent of the advantages of familiarity. Far more damaging to an incumbent's chances, however, is redrawing the lines to place the residences of two incumbents in the same district, thereby forcing at least one of them out of office. Unlike packing, which concedes vic-

${ }^{47}$ In Wright v. Rockefeller, 376 U.S. 52, 53-54 (1964), for example, Democrat Adam Clayton Powell intervened to defend a pro-Republican gerrymander of Manhattan. His own district was overwhelmingly safe, and the decision to pack as many of Manhattan's black and Puerto Rican voters into his district-thereby bleaching the adjacent district and making it a Republican seat-gave him greater influence than he would otherwise have enjoyed.

${ }^{48}$ A significant part of an incumbent's electoral advantage is a function of her constituents' familiarity with her. See Pamela S. Karlan, Loss and Redemption: Voting Rights at the Turn of a Century, 50 VAND. L. REV. 291, 302 n.31 (1997) (discussing evidence that reshuffling of districts can deprive incumbents of their advantage). 
tory to some number of out-party legislators, shacking is a declaration of redistricting war. Shacking requires one-party dominance of the redistricting process and ensures protracted challenges through litigation. By contrast, as we shall see, packing may be the result of political accommodation among all incumbents and may, as a result, fly below the litigation radar.

Standing alone, the Bandemer plurality standard gave a "'constitutional green light' to would-be gerrymanderers." ${ }^{49}$ Ironically, another doctrinal development not only made it safe to engage in partisan line-drawing, but made it attractive to assert partisanship as the motivation for challenged lines. Seven years after Bandemer, the Supreme Court recognized a fourth, "analytically distinct" equal protectionbased challenge to redistricting plans in Shaw v. Reno. ${ }^{50}$ In Shaw and its progeny, the Court held that excessive reliance on race in the redistricting process was constitutionally impermissible: if race was the "predominant factor motivating the legislature's decision to place a significant number of voters within or without a particular district," the district would have to satisfy strict scrutiny. ${ }^{51}$ But after nearly a decade's worth of confused and confusing case law, the Court announced in Easley v. Cromartie $e^{52}$ that a state's consideration of race would not trigger strict scrutiny if partisan political considerations played an equally important role in the configuration of the challenged districts. ${ }^{53}$ In effect, partisan motivation for gerrymanders served as a defense to Shaw claims, not as a prima facie element of a Bandemer suit. Moreover, although the Shaw cases reflected concern with the redistricting process, rather than the electoral consequences of redistricting for a voter's ability to elect the candidate of her choice, a plaintiff had standing to challenge only the configuration of the district in which she lived $;^{54}$ the claim that the process as a whole was tainted by impermissible considerations was off the table. ${ }^{55}$ Thus, the

\footnotetext{
49 Bandemer, 478 U.S. at 173 (Powell, J., concurring in part and dissenting in part) (footnote omitted).

509 U.S. 630, 652 (1993).

${ }^{51}$ Miller v. Johnson, 515 U.S. 900, 913, 916 (1995).

52 U.S. 234 (2001).

Id. at $241-42$.

${ }^{54}$ See United States v. Hays, 515 U.S. 737, 745 (1995) (denying standing to voters who challenged a district to which they were not assigned).

${ }^{55}$ Indeed, in Sinkfield v. Kelley, 531 U.S. 28 (2000) (per curiam), the Supreme Court went so far as to deny standing to plaintiffs who it concluded were really "challenging their own majority-white districts as the product of unconstitutional racial gerrymandering under a redistricting plan whose purpose was the creation of majority-
} 
Court turned all claims-even claims that were fundamentally about political structure-into claims of individual rights. This transformation has come to have important effects on what kinds of claims the Court sees, and what kinds of issues are never squarely confronted.

The upshot of forty years of judicial oversight was a thicket of constitutional constraints. Each decade, the political branches drew their plans in light of the existing law, only to find that the Court would announce new standards. And each decade, the Court would discover that the principles it had laid out during the prior decade were being circumvented by ingenious new techniques. Both the Court and the political branches were shooting at constantly moving targets.

\section{VIETH V. JUBELIRER AND FIRST-ORDER JUDICIAL REVIEW}

As a result of the 2000 census, Pennsylvania was entitled to nineteen seats in the House of Representatives, a decrease of two from its post-1990 allocation. ${ }^{56}$ While Pennsylvania is a politically competitive state-under a court-ordered plan drawn in 1992, the state's congressional delegation consisted of eleven Republicans and ten Democrats, and candidates from each party regularly carry the state in statewide elections ${ }^{57}$-Republicans controlled both houses of the state legislature as well as the governorship at the time redistricting occurred.

Spurred on by prominent national figures in the Republican party ranging from Speaker of the House Dennis Hastert to presidential political consultant Karl Rove, who urged them to draw a plan that would retaliate against the Democratic Party for what they saw as proDemocratic redistricting plans in other states, ${ }^{58}$ the Pennsylvania Republicans drew a nakedly partisan plan.

Of course, since Pennsylvania was losing two seats, at least two sets of incumbents had to be paired. Thus, given Republican control of the process, one might have expected a plan that forced the

\footnotetext{
minority districts" adjacent to their districts. $I d$. at 30 .

${ }^{56}$ Vieth v. Jubelirer, 124 S. Ct. 1769, 1773 (2004) (plurality opinion).

${ }^{57}$ See Erfer v. Commonwealth, 794 A.2d 325, 345-48 (Pa. 2002) (providing details about the political complexion of Pennsylvania). In 2000, for example, there were five statewide elections on the ballot, ranging from President to state auditor. Democratic candidates received between $43 \%$ and $57 \%$ of the vote for the various offices. Id. at 347.

${ }^{58}$ See Vieth v. Pennsylvania, 188 F. Supp. 2d 532, 535 (M.D. Pa. 2002) (three-judge court) (describing how "prominent national figures in the Republican party" pressured Pennsylvania Republican officials to approach redistricting "as a punitive measure against Democrats").
} 
Democrats to bear the entire loss, producing an 11-8 breakdown. But the Republicans did better, crafting a plan designed to pick up two or three additional seats and to give the Republicans a 13-6 or 14-5 advantage. ${ }^{59}$ Not only did they pair two sets of Democratic incumbents against one another, but they also moved a fifth Democrat into a decisively Republican district with a Republican incumbent and they created an open seat. ${ }^{60}$ To accomplish this feat required taking some liberties with the map, including splitting three times as many political subdivisions between or among districts as the predecessor plan had done, drawing an "irregular, 'dragon-shaped' district" in southeastern Pennsylvania that yoked together "several wholly distinct, unconnected communities of interest," ing a "jagged and irregular line" to separate two districts in the western part of the state. ${ }^{62}$ In short, the Democrats were cracked, packed, and shacked.

While the Republican-drawn plan was irregular along a number of dimensions, ranging from the procedural to the cartographic, it was quite precise along one. Given its population, the ideal House district size in Pennsylvania was $646,371.2$ persons. The Republicans produced a plan in which the most populous district exceeded the ideal by only 8.8 people, while the three least populous districts were only 10.2 people short, for a total deviation of nineteen people. ${ }^{63}$ These deviations are, almost needless to say, entirely without meaning. Both the ideal district size and the deviations from the ideal are a product of the decennial census enumeration, which itself carries a margin of error of about $2 \%$. The "deviation" from the ideal in the Pennsylvania setting had no discernible bearing on actual representa-

\footnotetext{
${ }^{59}$ In the current House of Representatives, under a slightly revised plan, the Republicans actually hold a 12-7 advantage. See OfFICE OF THE CLERK, U.S. House OF REPRESENTATIVES, OFFICIAL LIST OF MEMBERS OF THE HOUSE OF REPRESENTATIVES OF THE UNITED STATES (Sept. 1, 2004), available at http://clerk.house.gov/members/ olm108.html; see also infra note 136 (discussing the vagaries of predicting outcomes precisely).

${ }^{60}$ See Vieth v. Pennsylvania, 195 F. Supp. 2d 672, 674 (M.D. Pa. 2002) (per curiam) (three-judge court) (describing the configuration of the plan). In addition, many of the incumbent Democrats were located in districts whose boundaries had been significantly redrawn to remove many of their prior constituents, thus making them less functionally "incumbent." Id. at 678 .

${ }^{61}$ Erfer, 794 A.2d at 351.

${ }^{62}$ Id. The overall map was "significantly less compact than under prior plans in Pennsylvania," and four of the districts were less compact than the least compact district in the predecessor plan. Id. at 351-52.

${ }^{63}$ Vieth, 188 F. Supp. 2d at 535.
} 
tion and could only be viewed as a crude instrument to ferret out improper motives along other dimensions.

Bearing out Alexis de Tocqueville's observation that "[s]carcely any political question arises in the United States that is not resolved, sooner or later into a judicial question, ${ }^{64}$ various Democrats rushed into state and federal court to challenge the plan. Although the state supreme court agreed that the Republicans had deliberately constructed a map designed to reward themselves with a disproportionate number of seats, it refused to strike down the plan as an unconstitutional political gerrymander because the plaintiffs had failed to show the required discriminatory effect: being "shut out of the political process" altogether. ${ }^{65}$ First, the plaintiffs had not alleged that "a winning Republican congressional candidate "[would] entirely ignore the interests' of those citizens within his district who voted for the Democratic candidate." were "safe seats' for Democratic candidates" ${ }^{\text {"67 }}$ - a consequence of Republican "packing" of Democratic voters ${ }^{68}$ - "further undermin[ed]" the conclusion that Democrats had been entirely shut out. ${ }^{69}$

In federal court, the plaintiffs initially fared better. Relying on Karcher, a three-judge district court held that the state had failed to show that the nineteen-person deviation was "necessary to achieve some legitimate goal." ${ }^{70}$ The state had argued that the deviation

${ }^{64} 1$ AleXis De TOCQUeville, DEMOCRACY IN AMERICA 290 (Francis Bowen trans., Vintage Books 1945) (1835).

${ }^{65}$ Erfer, 794 A.2d at 334. In a prior decision, the Pennsylvania Supreme Court had held that political gerrymandering claims were justiciable under two provisions of the Pennsylvania Constitution-the equal protection guarantee, PA. CONST. art. I, §§ 1, 26, and the free and equal elections clause, art. 1, § 5. In re 1991 Pa. Legislative Reapportionment Comm'n, 609 A.2d 132, 141-42 (Pa. 1992). In re 1991 Reapportionment adopted, as a construction of the state constitution, the plurality view in Davis $v$. Bandemer, 478 U.S. 109 (1986). As construed by the Pennsylvania courts, to prove a discriminatory effect required a plaintiff to "show two things: first, he must show that [a politically] identifiable group has been, or is projected to be, disadvantaged at the polls; second, he must establish that by being disadvantaged at the polls, the identifiable group will 'lack ... political power and [be denied] fair representation."' Erfer, 794 A.2d at 332 (quoting Bandemer, 478 U.S. at 139).

${ }^{66}$ Erfer, 794 A.2d at 334 (quoting Bandemer, 478 U.S. at 132).

${ }^{67}$ Id. (internal quotation marks omitted).

${ }^{68}$ The four most politically lopsided districts in the state were all overwhelmingly Democratic. See id. at 348-49 (discussing the effects of the redistricting act). These districts all "wasted" significant numbers of Democratic votes. By contrast, the Republicans spread their likely supporters more efficiently across a greater number of districts. Id.

${ }^{69}$ Id. at 334.

${ }^{70}$ Vieth v. Pennsylvania, 195 F. Supp. 2d 672, 677 (M.D. Pa. 2002) (per curiam) 
avoided the need to split precincts with its attendant increase in election administration costs. But the district court found that it would have been possible to draw a zero-deviation map that split no precincts. ${ }^{71}$ As for the various "neutral legislative policies that the Karcher Court [had] stated would justify a congressional redistricting plan with some deviations," ${ }^{, 72}$ the district court termed the challenged plan a dismal effort. In contrast to various hypothetical plans presented by the plaintiffs at trial to show that the nineteen-person deviation was avoidable, the challenged plan "contain[ed] the least compact districts" and "split[] the most counties ... and municipalities." Moreover, it was disqualifyingly selective in applying more politically salient "neutral" criteria: it retained "the cores of prior districts . . . only for districts containing Republican incumbents" ", and "fail[ed] most miserably" to avoid contests between incumbents. ${ }^{75}$ As the district court succinctly concluded, "it is clear that Karcher's neutral criteria were not high on the priority list in enacting [the challenged plan]." ${ }^{, 76}$

The challengers' victory was fleeting indeed. Consistent with existing practice, the district court gave the state an opportunity to draw a new plan that cured the constitutional defects. While the state's remedial plan continued to "jettison[] every other neutral nondiscriminatory redistricting criteria that the Supreme Court has endorsed in one person, one vote cases," ${ }^{, 77}$ it did manage to eliminate any avoidable population deviation. Thus, the district court held, the plaintiffs could not establish a violation of Article I, Section 2's equipopulosity requirement. ${ }^{78}$

This threw the plaintiffs back on their real objection to the plan: its partisan consequences. But here, the district court, like the Pennsylvania Supreme Court, held that the plaintiffs could not meet the standard set out by the Davis $v$. Bandemer plurality: that "the electoral system is arranged in a manner that will consistently degrade a voter's,

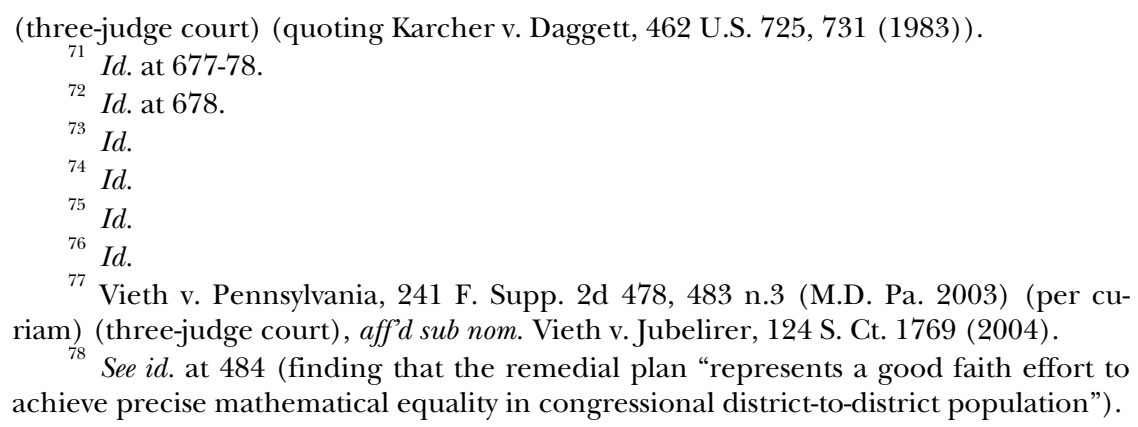


or group of voters', influence on the political process as a whole."79 Even if the challenged plan was in fact "rigged to guarantee" the election of Republicans, ${ }^{80}$ Democrats retained their ability to register, to vote, to organize, to raise funds for their candidates, and to speak out on matters of public concern: ${ }^{81}$

The Constitution protects against partisan gerrymandering only because of the effect that it has on the individual's ability to exercise the fundamental right to vote. It goes without saying that political parties, although the principal players in the political process, do not have the right to vote. Therefore, their health is a non-issue in the constitutional analysis. $^{82}$

Accordingly, the district court reaffirmed its earlier dismissal of the plaintiffs' political gerrymandering claim.

On appeal, the Supreme Court affirmed. As in Davis v. Bandemer, the Court was unable to unite behind a single opinion. Justice Scalia's plurality opinion would have overruled Bandemer and declared political gerrymandering claims nonjusticiable. ${ }^{83}$ Justice Kennedy, who provided the critical fifth vote for the Court's judgment, condemned the Pennsylvania map ("Here, one has the sense that legislative restraint was abandoned."), ${ }^{84}$ floated the suggestion that "the First Amendment may offer a sounder and more prudential basis for intervention than does the Equal Protection Clause, ${ }^{, 85}$ but voted to affirm the dismissal of the plaintiffs' complaint because no one had yet presented him with a workable test for adjudicating political gerrymandering claims. Justice Stevens, Justice Souter (joined by Justice Ginsburg), and Justice Breyer dissented. None of them embraced the Bandemer plurality's approach; each of them proposed a different test for reviewing claims of unconstitutional political gerrymandering; and each of them would have held that, under his test, the plaintiffs' complaint stated a claim.

\footnotetext{
${ }^{79}$ Vieth v. Pennsylvania, 188 F. Supp. 2d 532, 544 (M.D. Pa. 2002) (quoting Bandemer, 478 U.S. at 132).

${ }^{80} I d$. at 546.

${ }^{81}$ See id. at 547 (describing Democratic voters' access to the broader political process).

${ }^{82} I d$. at 546.

${ }^{83}$ See Vieth v. Jubelirer, 124 S. Ct. 1769, 1778 (2004) ("Eighteen years of judicial effort with virtually nothing to show for it justify us in revisiting the question whether the standard promised by Bandemer exists. ... [ [N]o judicially discernible and manageable standards for adjudicating political gerrymandering claims have emerged. Lacking them, we must conclude that political gerrymandering claims are nonjusticiable and that Bandemer was wrongly decided.").

${ }^{84} I d$. at 1798 (Kennedy, J., concurring in the judgment).

${ }^{85} I d$.
} 
Ultimately, the plurality opinion rested on only one of Baker $v$. Carr's six bases for finding a claim to be a nonjusticiable political question-namely, "a lack of judicially discoverable and manageable standards for resolving it." ${ }^{, 6}$ But it began with an intriguing feint in the direction of treating gerrymandering claims as nonjusticiable because of "a textually demonstrable constitutional commitment of the issue to a coordinate political department." ${ }^{, 87}$ In the course of a discussion of the long history of political gerrymandering, Justice Scalia declared: "It is significant that the Framers provided a remedy for such practices in the Constitution. Article 1, [Section] 4, while leaving in state legislatures the initial power to draw districts for federal elections, permitted Congress to 'make or alter' those districts if it wished." ${ }^{88}$ Over the years, Congress has imposed a variety of restrictions on states' selections of their congressional delegations, ranging from the still-existing requirement that they elect Representatives to single-member districts to now-abandoned requirements that districts be composed of compact and contiguous territory. And Justice Scalia pointed to a comment made by a delegate to the Massachusetts ratification convention, who warned that states "might make an unequal and partial division of the states into districts for the election of representatives":

Without these powers in Congress, the people can have no remedy; [b] ut the 4th section provides a remedy, a controlling power in a legislature, composed of senators and representatives of twelve states, without the influence of our commotions and factions, who will hear impartially, and preserve and restore to the people their equal and sacred rights of election. $^{89}$

The Pennsylvania experience shows how the original constitutional design has been undermined by the emergence of national political parties. The senators and representatives of the now forty-nine other states are not "without the influence of [Pennsylvania's] commotions and factions." To the contrary, politicians from other states contributed to the commotion in Pennsylvania because they were part of the same faction. For example, Dennis Hastert, the Speaker of the House who hails from Illinois, actively participated in crafting the Pennsylvania Republican plan, as did Karl Rove, the White House

${ }^{86}$ Id. at 1776 (quoting Baker v. Carr, 369 U.S. 186, 217 (1962)).

${ }^{87} \mathrm{Id}$.

${ }^{88} I d$. at 1775 .

${ }^{89} I d$. (quoting 2 Debates ON THE AdOPTION OF THE FEDERAL CONSTITUTION 27 (J. Elliot ed., 2d ed. 1876)). 
politicsmeister, and Tom DeLay, the House majority whip from Texas. ${ }^{90}$ As the Court itself recognized in the term limits cases, the House of Representatives is a national body even if its members are elected by the people of particular states. ${ }^{91}$

Nonetheless, Justice Scalia's opinion raises one of the most farreaching constitutional questions in this area of law, one not addressed squarely by any of the dissents. Our constitutional framework both assumes a democratic politics and that the separation of powers between states and the federal government and among the branches of the federal government will sufficiently channel politics to avoid the perils of majoritarian attacks on the democratic process itself. But the Framers' conception of popular politics existing at the decidedly local level failed historically. With the rise of national political parties, the politics of the people became "domesticated," to use Dean Kramer's formulation, ${ }^{92}$ and regional checks succumbed increasingly to the national agendas of the political parties. What happens, then, when the Constitution gets it wrong? Justice Scalia appears to want it both ways. He recognizes that the Framers saw a threat to democratic governance from the way states might draw their congressional districts and that they addressed the threat, but he proposes to stand aside on the grounds that the political mechanism they explicitly included in the Constitution provides the only remedy, even though national intervention now actually exacerbates the problems of partisanship rather than dampening them. ${ }^{93}$

${ }^{90}$ Jeffrey Toobin, The Great Election Grab: When Does Gerrymandering Become a Threat to Democracy?, New Yorker, Dec. 8, 2003, at 63, 65 (quoting a letter from DeLay and Hastert sent to Pennsylvania legislators during the redistricting struggles, saying " $[\mathrm{w}] \mathrm{e}$ wish to encourage you in these efforts, as they play a crucial role in maintaining a Republican majority in the United States House of Representatives").

${ }^{91}$ See U.S. Term Limits, Inc. v. Thornton, 514 U.S. 779, 803 (1995) ("In that National Government, representatives owe primary allegiance not to the people of a State, but to the people of the Nation... Representatives and Senators are as much officers of the entire Union as is the President.").

${ }^{92}$ Larry D. Kramer, The People Themselves: Popular Constitutionalism AND JUDICIAL REVIEW 167-68 (2004).

${ }_{93}$ This abstention is particularly interesting given Justice Scalia's recognition in the Fourth Amendment context that changes in technology have the power to shrink constitutional checks on governmental power and that the Constitution should be interpreted to prevent that shrinkage. See Kyllo v. United States, 533 U.S. 27, 34 (2001) (holding that use of technology not available to the general public to gather information constitutes a search, and explaining that this approach "assures preservation of that degree of privacy against government that existed when the Fourth Amendment was adopted"). 
By and large, the dissenting opinions avoided engagement with this structural issue. Instead, the dissenters adopted the same framework as the plurality and viewed the case primarily as a partisan discrimination claim. Here, the central problem for the dissenters, as for the plurality, was the need to distinguish permissible from impermissible partisanship. No member of the Court was prepared to hold that partisan considerations were wholly illegitimate or that any reliance on political factors whatsoever should trigger judicial skepticism. Moreover, no member of the Court was prepared to embrace a mathematical test: either a requirement of simple proportionality between a party's share of the votes and its share of the seats or the more complex test proposed by the plaintiffs: that the challenged map can thwart a group's ability to translate a majority of votes into a majority of seats. Thus, the question was whether it was possible to articulate a judicially manageable test for deciding when partisanship had become constitutionally excessive. The plurality doubted this could be done. It saw all the proposed tests as dissolving into
a totality-of-the-circumstances analysis, where all conceivable factors, none of which is dispositive, are weighed with an eye to ascertaining whether the particular gerrymander has gone too far ... whether it is not "fair." "Fairness" does not seem to us a judicially manageable stan- dard... Some criterion more solid and more demonstrably met than that seems to us necessary to enable the state legislatures to discern the limits of their districting discretion, to meaningfully constrain the discre- tion of the courts, and to win public acceptance for the courts' intrusion into a process that is the very foundation of democratic decisionmak- ing.

By contrast, each of the dissenters saw some way of identifying excess. One of the puzzles of Vieth is why it produced so much separate writing, since so many common threads ran through the three dissents. Justice Stevens would have "appl[ied] the standard set forth in the Shaw cases [to] ask whether the legislature allowed partisan considerations to dominate and control the lines drawn, forsaking all neutral principles." ${ }^{95}$ Under that test, "if no neutral criterion can be identified to justify the lines drawn, and if the only possible explanation for a district's bizarre shape is a naked desire to increase partisan strength, then no rational basis exists to save the district from an equal protection challenge., ${ }^{96}$ Given his general hostility to Shaw challenges,

\footnotetext{
${ }^{94}$ Vieth, 124 S. Ct. at 1784.

${ }^{95}$ Id. at 1812 (Stevens, J., dissenting).

${ }^{96} \mathrm{Id}$.
} 
this suggested that Justice Stevens was unlikely to find very many constitutional violations, but it at least held open the possibility of judicial intervention and thereby could perhaps "mitigate the current trend under which partisan considerations are becoming the be-all and endall in apportioning representatives. ${ }^{, 7}$

Justice Souter, joined by Justice Ginsburg, proposed a five-element prima facie case that largely distilled the factors identified by Justice Stevens, ${ }^{98}$ with the additional wrinkle that he would "treat any showing of intent in a major-party case as too equivocal to count unless the entire legislature were controlled by the governor's party (or the dominant legislative party were veto-proof)."

Justice Breyer differed from the other dissenters in seeing a more legitimate role for partisan political considerations in the districting process: " $[\mathrm{t}]$ he use of purely political boundary-drawing factors, even where harmful to the members of one party, will often nonetheless find justification in other desirable democratic ends, such as maintaining relatively stable legislatures in which a minority party retains significant representation." ${ }^{100}$ But he saw one "serious, and remediable, abuse, namely the unjustified use of political factors to entrench a minority in power." ${ }^{101}$ Entrenchment would be unjustified, he suggested, when it was produced "by the use of partisan boundary drawing criteria in the way that Justice Stevens describes, i.e., a use that both departs from traditional criteria and cannot be explained other than by efforts to achieve partisan advantage." 102

A number of scholars have observed that the Rehnquist Court has shown an especial fondness for First Amendment claims. Perhaps, therefore, we should not be surprised by Justice Kennedy's suggestion that the First Amendment might become the new "last resort of constitutional arguments" ${ }^{\text {"103 }}$ about political gerrymandering. What is puzzling about Justice Kennedy's opinion is his optimism that the First

${ }^{97} I d$.

98 See id. at 1817-19 (Souter, J., dissenting) (describing his proposed test).

99 Id. at 1819.

${ }^{100} I d$. at 1825 (Breyer, J., dissenting).

101 Id.

102 Id. at 1827-28.

103 In Buck v. Bell, 274 U.S. 200, 208 (1927), the notorious involuntary sterilization case, Justice Holmes so denominated equal protection claims. Justice Scalia's references in Vieth to "eighteen years" of lower courts "set wandering in the wilderness," Vieth, 124 S. Ct. at 1791, and "judicial effort with virtually nothing to show for it," $i d$. at 1778, are reminiscent of another well-remembered phrase from Buck v. Bell: "[t]hree generations of imbeciles are enough.” 274 U.S. at 207. 
Amendment may somehow provide a more "limited and precise" tool for judicial intervention. ${ }^{104}$ To be sure, the Court has held in the political patronage cases that it violates individuals' First Amendment rights to burden or penalize them "because of their participation in the electoral process, their voting history, their association with a political party, or their expression of political views." ${ }^{105}$ But the burden that the plaintiffs in the patronage cases experienced fell on them outside the political process: they lost jobs as public defenders or road workers or were denied contracts to haul trash or tow cars. To win their cases, the plaintiffs had to show that they would have received or retained the job or contract had politics played no part in the government's decision. To assess that showing did not require the reviewing court to articulate a political philosophy or to decide in the abstract what constituted a fair employment or contracting policy.

By contrast, in a political gerrymandering case, the question whether "an apportionment has the purpose and effect of burdening a group of voters' representational rights" ${ }^{\prime 16}$ requires deciding what voters' "representational rights" are. The First Amendment itself cannot be the source of those rights, for it has nothing to say about which groups of voters deserve to have districts drawn that reflect their interests. All districting has political consequences, and those consequences are largely predictable to politically sophisticated actors. Thus, those consequences are rarely entirely unintentional. Indeed, it is safe to conclude that the sophistication of political actors in contemporary redistricting eliminates any explanation for line drawing other than intentionality. But those consequences, even if intentional, may have nothing to do with voter-oriented representational

104 Vieth, 124 S. Ct. at 1793, 1797-98 (Kennedy, J., concurring in the judgment).

${ }^{105}$ Id. at 1797 (citing Elrod v. Burns, 427 U.S. 347 (1976) (plurality opinion)). For elaboration of the Court's antipatronage principle, see Board of County Commissioners v. Umbehr, 518 U.S. 668, 686 (1996) (extending the constitutional prohibition on patronage to government contracting decisions); O'Hare Truck Service, Inc. v. City of Northlake, 518 U.S. 712, 720 (1996) (same); Rutan v. Republican Party, 497 U.S. 62, 74-79 (1990) (extending the rule to decisions regarding hiring and promotion). We long ago noted a fundamental tension in the Court's jurisprudence of politics: "Political patronage is constitutionally suspect because it may 'retard' the democratic process by 'entrench [ing] ... one or a few parties to the exclusion of others'... but the state's 'strong interest' in a 'healthy two-party system' can justify 'election regulations that may, in practice, favor the traditional two-party system.'” Pamela S. Karlan, The Fire Next Time: Reapportionment After the 2000 Census, 50 StAN. L. REV. 731, 732 (1998) (quoting Elrod, 427 U.S. at 369, and Timmons v. Twin Cities Area New Party, 520 U.S. 351, 366-67 (1997)) (footnote omitted).

${ }^{106}$ Vieth, 124 S. Ct. at 1797 (Kennedy, J., concurring in the judgment). 
rights. They may be focused entirely, as a matter of Feeney-style discriminatory "purpose," 107 on ensuring the protection of incumbent legislators rather than on substantive voting records or the denial of constituent services. Saying that the distinction between relying on the Equal Protection Clause and relying on the First Amendment lies in the fact that "equal protection analysis puts its emphasis on the permissibility of an enactment's classifications" ${ }^{108}$ while First Amendment analysis "concentrates on whether the legislation burdens the representational rights of the complaining party's voters," ${ }^{109}$ as Justice Kennedy would have it, simply ignores the question that "representational rights" are as yet undefined.

When all was said and done, the result of Vieth was that a majority of the Court had expressed unwillingness to entertain challenges to political gerrymanders under any as-yet articulated standard. At the same time, a different majority of the Court had expressed the view that political gerrymanders posed a serious threat to fundamental constitutional values.

\section{COX V. LARIOS AND SECOND-ORDER JUDICIAL REVIEW}

The post-2000 Georgia state legislative redistricting was a Democratic counterpart to the Republican-dominated process in Pennsylvania. From 1990 to 2000, the population of northern Georgia, largely the urban and suburban areas surrounding Atlanta, grew at a much faster rate than the population of rural southern Georgia. ${ }^{110}$ Moreover, the fastest-growing counties in the state were Republicanleaning. ${ }^{111}$ Nonetheless, at the time of the redistricting, Democrats still

${ }^{107}$ In Personnel Administrator v. Feeney, 442 U.S. 256 (1978), the Court explained that

"[d]iscriminatory purpose" ... implies more than intent as volition or intent as awareness of consequences. It implies that the decisionmaker, in this case a state legislature, selected or reaffirmed a particular course of action at least in part "because of," not merely "in spite of," its adverse effects upon an identifiable group.

$I d$. at 279 (internal citation and footnote omitted). We have explained elsewhere the incoherence of even attempting to apply Feeney to redistricting cases, given the likely primacy of incumbent protection and personal political advantage (as opposed to party-level considerations) in most plans. Pamela S. Karlan, Still Hazy After All These Years: Voting Rights in the Post-Shaw Era, 26 CuMB. L. REV. 287, 301-02 (1996).

${ }^{108}$ Vieth, 124 S. Ct. at 1798 (Kennedy, J., concurring in the judgment).

${ }^{109}$ Id

${ }^{110}$ Larios v. Cox, 300 F. Supp. 2d 1320, 1323 (N.D. Ga.) (per curiam) (three-judge court), aff'd, 124 S. Ct. 2806 (2004).

${ }^{111} I d$. at 1323. 
controlled both houses of the Georgia legislature and the governorship.

The Democrats rejected Republican-proposed redistricting guidelines that would have required adherence to traditional redistricting criteria, such as district compactness and contiguity; they failed to consult Republicans in crafting the particular plans that were adopted; and they rejected Republican-proposed alternative plans. ${ }^{112}$ Although the redistricting software the legislature used and the available data would have enabled the drafters to draw plans with no deviations, the legislature adopted redistricting guidelines that provided only that "the population deviation of each plan should not exceed an overall deviation of $10 \% . "$."13 State legislators believed that "there was a 'safe harbor' of $+/-5 \%$ in the reapportionment of state legislative districts and, therefore, that population deviations not rising to that level did not have to be supported by any legitimate state interest."114

As in Pennsylvania, the Georgia plan involved cracking, packing, and shacking. The House plan, for example, split eighty counties into 266 parts. ${ }^{115}$ While nine of the 105 incumbent Democrats were paired against other incumbents, thirty-seven of the seventy-four incumbent Republicans were paired. ${ }^{116}$ And sometimes the location of district lines was especially blatant: one Republican senator was placed in a majority-Democratic district with a Democratic incumbent, while an open district was drawn within two blocks of her house. ${ }^{117}$

Georgia is a covered jurisdiction under section 5 of the Voting Rights Act of $1965 .{ }^{118}$ Thus, before the state could implement its reapportionment plan, it was required to show that the plan would not cause, and was not intended to cause, a retrogression in minority voting strength. The plan raised complicated questions about how the nonretrogression standard should be applied given profound changes in the partisan composition of the South since 1965, and produced an important, and closely divided 2003 decision by the Supreme Court in Georgia v. Ashcroft. ${ }^{119}$

${ }^{112} I d$. at 1324

${ }^{113} I d$. at 1325 (internal quotation marks and brackets omitted).

${ }^{114} I d$.

115 See Larios v. Cox, 314 F. Supp. 2d 1357, 1371 (N.D. Ga. 2004) (three-judge court) (describing the plan).

${ }^{116}$ Cox v. Larios, 124 S. Ct. 2806, 2807 (2004) (Stevens, J., concurring).

117 Larios v. Cox, 300 F. Supp. 2d 1320, 1330 (N.D. Ga.) (per curiam) (three-judge court), aff'd, 124 S. Ct. 2806 (2004).

11842 U.S.C. $\$ 1973$ c (2000); see also Georgia v. United States, 411 U.S. 526, 528 n.1 (1973) (noting Georgia's inclusion within the list of covered jurisdictions).

${ }^{119} 539$ U.S. 461 (2003). For an analysis of the case, see Pamela S. Karlan, Georgia 
Following the Supreme Court's decision, a three-judge district court in Georgia took up a challenge to the plan brought by Republican voters who lived in some of the more populous districts. They claimed both that the plan was an unconstitutional political gerrymander and that it violated one person, one vote.

The district court dismissed the plaintiffs' claims of unconstitutional gerrymandering for failing to satisfy the consistent degradation standard of Davis v. Bandemer, but struck down the plan as a violation of one person, one vote. ${ }^{120}$ It observed that the Supreme Court had suggested that as a general matter, deviations under $10 \%$ were insufficient even to establish a prima facie case. ${ }^{121}$ But it did not believe that the Court had established a "safe harbor." ${ }^{122}$ And on the facts of this case, it held that the deviation was impermissibly discriminatory. First, with respect to the desire of rural and inner-city legislators to retain their legislative influence even though their relative share of the population had decreased, the district court concluded that this desire could not be "reconciled with the command of Reynolds." tecting incumbents could constitute a legitimate state policy that might permit population deviations, the Georgia plans implemented incumbent protection

\begin{abstract}
in a blatantly partisan and discriminatory manner, taking pains to protect only Democratic incumbents. The vast majority of districts with negative population deviations were held by Democratic incumbents, while the majority of overpopulated districts were held by Republican incumbents. Moreover, both the House and Senate Plans actually pitted numerous Republican incumbents against one another, while generally protecting their Democratic colleagues. ${ }^{124}$
\end{abstract}

Given its findings, the district court enjoined use of the state legislative plans.

The Supreme Court summarily affirmed, in a one-sentence opinion. ${ }^{125}$ Justice Stevens, in a concurrence joined by Justice Breyer, explained that the Court's recent decision in Vieth meant that "the equal-population principle remains the only clear limitation on im-

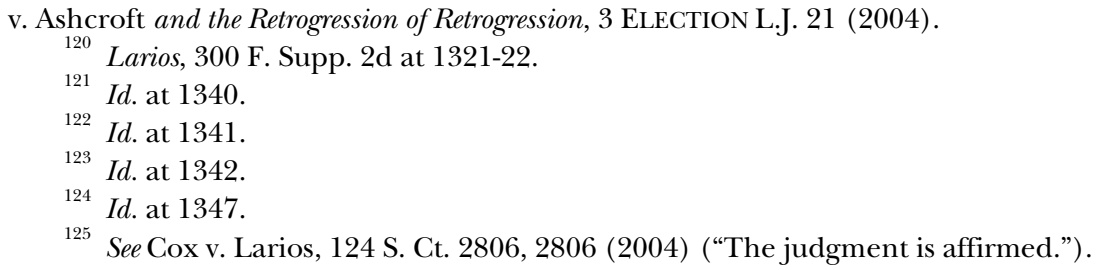


proper districting practices, and we must be careful not to dilute its strength." ${ }^{126}$ Thus, they embraced Justice Brennan's strategy in Karcher v. Daggett ${ }^{127}$ of using one person, one vote, with its appealing aura of objective mathematics as a vehicle for controlling otherwise constitutionally intractable questions of political philosophy. To them, the Georgia plan was "an impermissible partisan gerrymander" whose "selective incumbent protection" violated the "state legislature's fundamental duty to govern impartially." ${ }^{28}$

Justice Scalia, in a solo dissent, argued that the Court should have set the case for full briefing and oral argument:

A substantial case can be made that Georgia's redistricting plan did
comply with the Constitution. Appellees do not contend that the popu-
lation deviations-all less than $5 \%$ from the mean-were based on race
or some other suspect classification. They claim only impermissible politi-
cal bias-that state legislators tried to improve the electoral chances of
Democrats over Republicans by underpopulating inner-city and rural
districts and by selectively protecting incumbents, while ignoring "tradi-
tional" redistricting criteria....

The problem with this analysis is that it assumes "politics as usual" is not itself a "traditional" redistricting criterion. In the recent decision in Vieth $v$. Jubelirer, all but one of the Justices agreed that it is a traditional criterion, and a constitutional one, so long as it does not go too far. It is not obvious to me that a legislature goes too far when it stays within the $10 \%$ disparity in population our cases allow. To say that it does is to invite allegations of political motivation whenever there is population disparity, and thus to destroy the $10 \%$ safe harbor our cases provide. Ferreting out political motives in minute population deviations seems to me more likely to encourage politically motivated litigation than to vindicate political rights. ${ }^{129}$

Thus, while Vieth essentially cuts off first-order political gerrymandering claims-that is, plaintiffs cannot get a plan struck down simply by showing that it constitutes an excessively partisan gerrymanderCox v. Larios restores an opportunity for second-order judicial review of political gerrymanders: if a plan contains any population deviations, a court may decide that the deviations are caused by impermissible partisanship and strike the plan down as a formal matter for failure to

${ }^{126}$ Id. at 2808 (Stevens, J., concurring).

127462 U.S. 725 (1983); see also IssaCharoff, KARLAN \& PILdEs, supra note 38, at 181 (discussing the use of one person, one vote to deal with issues of political gerrymandering).

${ }^{128}$ Larios, 124 S. Ct. at 2807-09 (Stevens, J., concurring) (quoting, in part, Vieth v. Jubelirer, 124 S. Ct. 1769, 1813 (2004)).

${ }^{129}$ Id. at 2809-10 (Scalia, J., dissenting) (internal citations omitted). 
comply with one person, one vote. ${ }^{130}$ But in order to hold that a deviation is unjustified, courts must necessarily develop some idea of where the line between constitutionally legitimate and constitutionally illegitimate partisanship falls. ${ }^{131}$ In short, they must do exactly what four of the Justices who rejected the plaintiffs' claims in Vieth-Chief Justice Rehnquist, Justice O'Connor, and Justice Thomas, who joined Justice Scalia's conclusion that these claims are nonjusticiable because there is "a lack of judicially discoverable and manageable standards for resolving" the issue, ${ }^{132}$ and Justice Kennedy, who saw no as-yet developed standard for adjudicating the claim-thought could not be done.

Is there some reason to prefer second-order adjudication of political gerrymandering claims to first-order adjudication? If there is, we don't see it. To be sure, once the system reequilibrates to the understanding that all deviations-and not simply those greater than $10 \%$ - may require neutral justifications, second-order adjudication may be less frequent than first-order challenges would have been. And perhaps tightening up the population deviation standards may foreclose some gerrymanders, or at least limit them at the margins. But it seems as if second-order adjudication is more arbitrary, since outcomes turn not primarily on the degree of partisanship-even though partisan considerations drove the plan, prompted the litigation, and explained the courts' intervention-but rather on the fortuity of essentially meaningless deviations among the districts' populations. Whatever the virtues of holding reapportionment to the one person, one vote rule of equal population, the normative foundations

${ }^{130}$ That tactic was not available in Vieth, since the legislature's second plan managed to attain absolute population equality. And presumably now that legislatures know there is no clear $10 \%$ safe harbor, they will tailor their plans to achieve lower population deviations in the future. (Still, Larios opens up the opportunity for challenges to plans drawn after the 2000 census under the belief that the state would never be called upon to justify the deviations involved.)

${ }^{131}$ As Justice Scalia observed during oral argument in a vote-dilution case one of us argued many years ago: "You don't know what watered beer is unless you know what beer is, right?" Transcript of Oral Argument at 8, Chisom v. Roemer, 501 U.S. 380 (1991) (Nos. 90-757, 90-1032), available at 1991 WL 636355. Similarly, to decide that the state's explanation cannot justify a particular population deviation requires finding one of two things: either that the articulated rationale is descriptively wrongthat is, it does not explain the deviation in the first place (which seems unlikely, in a case where partisanship is the rationale, since it would be odd for the defendants to claim partisanship if a less charged explanation is available)—or that the articulated rationale is normatively unacceptable.

${ }^{132}$ Vieth v. Jubelirer, 124 S. Ct. 1769, 1813 (2004) (quoting Baker v. Carr, 369 U.S. 186, 217 (1962)). 
of the equipopulosity rule are not sufficiently robust to justify on their own the result in Larios. Although there is apparent precision to the strict application of the equipopulation principle in Larios, the mathematical exactitude is compromised by the general imprecision of the underlying census enumeration, and the inclusion of children, aliens, and other disenfranchised individuals (such as ex-offenders)whose numbers can vary dramatically from district to district. ${ }^{133}$ Given the fact that the mathematical weight of citizens' votes is likely to vary significantly even in districts with identical populations, it is difficult to see why trivial population disparities should on their own be constitutionally suspect. ${ }^{134}$

Moreover, the implicit message of Cox $v$. Larios-that courts should attack political gerrymanders using whatever tool is availablemay produce litigation not only under one person, one vote, a principle whose invocation in litigation is essentially harmless to the broader political system, but also under doctrinal rubrics, such as section 2 of the Voting Rights Act or the Shaw cases, where the spillover effects of litigation positions are not so benign. It's one thing to create incentives for political parties to use claims of one person, one vote as stalking horses for partisan battles. It's quite another to give them incentives to cry "racism." That latter accusation can have toxic consequences for the political process as a whole.

There is no realistic possibility that courts will abandon adjudication of Voting Rights Act, Shaw, and one person, one vote claims. Thus, the cost of repackaging essentially partisan claims under one of these labels is something that needs to be considered in deciding whether or not to explicitly address claims of excessive partisanship. That is a task the Supreme Court has simply not undertaken.

${ }^{133}$ The practical effect of differences in the demographic composition of various districts on the weight of individual voters' votes can be enormous. For one particularly striking example, consider Los Angeles County. Although the population deviation among the county's five supervisorial districts was less than $0.68 \%$, there was a deviation among the districts of roughly $40 \%$ with respect to the numbers of citizens of voting age-the starting point for thinking about voting power. See Garza v. County of L.A., 918 F.2d 763, 773 nn. 4-5 (9th Cir. 1990) (showing district population data), cert. denied, 498 U.S. 1028 (1991).

${ }^{134}$ As John Ely once commented about the one person, one vote standard, "administrability is its long suit, and the more troubling question is what else it has to recommend it." ELY, supra note 40, at 121. For a discussion of the departures from exact population equalities already admitted in the application of the Reynolds rule, see Sanford Levinson, One Person, One Vote: A Mantra in Need of Meaning, 80 N.C. L. REV. 1269, 1278-84 (2002). 


\section{BEYOND THE DISCRIMINATORY GERRYMANDER}

Distasteful as the partisan gerrymandering of Georgia and Pennsylvania may be, it may actually reflect the less troubling form of contemporary gerrymandering, precisely for the reasons anticipated in Carolene Products. In both Georgia and Pennsylvania, the victims of partisan excess were the local representatives of the national political parties. The parties have both the incentives and the resources to do battle in both the political and judicial arenas. Whatever the illegitimacy of the linedrawing in Georgia and Pennsylvania, the one thing that can be said with certainty is that the claimed victims are neither discrete and insular nor incapable of seeking redress in the domain of politics.

But what exactly is the claimed harm in Vieth and Larios? Note that it is not that the electoral system was manipulated, or that elected representatives have been essentially immunized from accountability to the electorate. It is not even that shifts in popular opinion are unlikely to alter the composition of the legislature. Rather, the claim is that the particular manipulation of the redistricting process that produced the challenged plan did not provide an aliquot number of safe seats for members of the out-party's delegation. In both Georgia and Pennsylvania, one party claimed an entitlement to more legislative seats, and nothing more. Under the statistical test proposed by the petitioners in Vieth, for example, voter preferences on a statewide level served simply as a background measure for the entitlement-based claims of the Democrats. The only problem with the cracking, packing, and shacking that was undertaken along the way was that it deprived a political party of its expected number of seats. To the extent that the euphonious trio of gerrymandering techniques carries any normative force, it is because it represents a mechanism to frustrate the popular electoral will by rendering elected officials a selfperpetuating caste. The cases before the Court, however, completely ignored the question of district-level entrenchment.

Thus we return to the gulf between the popular perception of what was at stake in Vieth (and by extension what was wrong in the post-2000 round of redistricting) and the issue to which the Court addressed itself. Popular perception focused not on the balance of distributional outcomes between Democrats and Republicans, but rather on the astonishing lack of competitive elections for legislative office, ${ }^{135}$

${ }^{135}$ See, e.g., Stuart Taylor Jr., Should the Supreme Court Clean Up Its Own Mess?, 35 NAT'L J. 3796, 3796 (2003) ("The goal would be to clean up the incumbententrenching, polarizing, gerrymandered mess that redistricting has become, or at least 
what the Wall Street Journal would term the "Incumbent Protection Racket." ${ }^{, 136}$ In other words, the issues before the Court in Vieth and Larios may well be of relatively secondary significance. In the partisan gerrymandering context, the claimed victims of discrimination have ample recourse to political redress, even if not immediate satisfaction within the jurisdiction in question. But beyond the question of political redress, the magnitude of the risk of discriminatory partisan gerrymandering is overwhelmed by the fact of nondiscriminatory bipartisan gerrymandering that renders elections in the United States immune to voter preferences.

As an historical matter, it is true that, as well noted by Professor Pildes, the historic fragility of democracy has turned on the propensity of a governing party to use the instrumentalities of office to thwart future electoral challenge. ${ }^{137}$ Too many nations have witnessed the dispiriting pattern of fledgling democracies yielding "one man, one vote, one time." ${ }^{\prime 138}$ The American version of this phenomenon is more sub-

to strike down partisan gerrymanders so extreme as to mock majority rule.”); Frank Askin, Drawing over Democracy: By Ending Unfair Partisan Gerrymanders, the Court Can Restore the Power of Voting, LEGAL TIMES, Dec. 1, 2003, at 46 ("[S] tate legislatures, which create the districts from which representatives are elected, have all but abolished competitive House districts, guaranteeing long-term tenure to incumbents."); Editorial, Broken Democracy, WASH. POST, Nov. 10, 2002, at B6 (blaming corruption of the redistricting process for the fact that $98 \%$ of House incumbents seeking reelection in 2002 won "by margins that suggest that many of the races were never serious"); Marcia Coyle, High Court Will Weigh U.S. House Remapping: Gerrymandering Might Have Limits, NAT'L L.J., Dec. 8, 2003, at 1, 22 (discussing the recent backdrop of "a record low level of competitiveness and high rate of incumbent reelection in the 2002 congressional elections"); Norman Ornstein, High Court Should Halt Obsession with Redistricting, ROLL CALL, May 14, 2003 ("Redistricting has contributed mightily to the deep partisan and ideological division in Congress, while narrowing the range of competition to almost absurdly low levels."), available at 2003 WL 7690711; Editorial, Rescuing U.S. Democracy, WASH. POST, Dec. 15, 2003, at A30 ("[E]lections for the House of Representatives have become something of a farce; results of almost all of them can be predicted the day the districts get drawn.”); Editorial, Rigged Districts Rob Public of Choice, USA TODAY, Aug. 28, 3002, at A13 (opining that state legislatures under partisan control effectively choose members of Congress through their shaping of districts, ensuring few tight races on Election Day); David E. Rosenbaum, Justices Bow to Legislators in Political Gerrymander Case, N.Y. TIMES, Apr. 29, 2004, at A22 (discussing Pennsylvania's redistricting, which ensured victory for large numbers of incumbents); Editorial, The Gerrymandered Democrats, WALL ST. J., Nov. 5, 2002, at A22 (attributing the competitiveness of Senate races compared to House races as owing to the fact that "no one has yet found a way to gerrymander a state").

${ }^{136}$ Opinion, Incumbent Protection Racket, WALL ST. J., Aug. 15, 2003, at A8.

${ }^{137}$ Richard H. Pildes, Foreword, The Constitutionalization of Democratic Politics, 118 HARV. L. REV. (forthcoming 2004).

${ }^{138}$ The phrase "one man, one vote, one time" was coined by former Assistant Secretary of State and U.S. Ambassador to Syria and Egypt, Edward Djerjian. Ali Khan, A 
tle: we continue to have regularly scheduled elections, but elected officials from both major parties unite to ensure that the election results are foreordained.

Whereas a partisan gerrymander is a declaration of war, a bipartisan gerrymander is a nonaggression pact between the parties in which they agree to divide up a state in favor of incumbent sinecure. Democratic incumbents are put in districts that are safely Democratic; so too for Republicans. The result on the day of the general election can be that elections are simply not competitive at all; safe districts for each party will reliably vote for whatever candidate emerges from the party primary. The facts seemingly speak for themselves. In the first postreapportionment elections in 2002, only four House incumbents lost to their challengers, and only forty-three incumbents received less than $60 \%$ of the major-party vote. ${ }^{139}$ Competition was so absent in some states that over one-third of state congressional representative delegations experienced no change during the 2002 election-indeed, just over $18 \%$ of House seats were uncontested by a major party. ${ }^{140}$ Considering that the traditional definition of a landslide in American politics is a victory by greater than a 60-40 margin, it turns out that redistricting is in most states a courtly process by which political insiders assure themselves a whopping electoral cushion. The same result is revealed using a less exacting measure than a landslide. One conventional shorthand is to define a competitive district as one that is won by less than a 55-to-45 margin. In the 2002 House elec-

Theory of Universal Democracy, 16 WIS. INT'L L.J. 61, 106 n.130 (1997). The historic basis for Djerjian's assessment is unfortunately not hard to discern. For example, between 1967 and 1991, no country in Africa experienced power passing from one elected government to another. DONALD L. HOROWITZ, A DEMOCRATIC SOUTH AFricA? CONSTITUTIONAL ENGINEERING IN A DiVIDED SOCIETY 239 (1991).

${ }^{139}$ Sam Hirsch, The United States House of Unrepresentatives: What Went Wrong in the Latest Round of Congressional Redistricting, 2 ELECTION L.J. 179, 182-83 \& tbl.1 (2003); see also Daniel R. Ortiz, Got Theory?, 153 U. PA. L. Rev. 459, 477 (2004) (same). See generally FED. Elections COMM'N, FEDERAL EleCtions 2002: EleCtion ReSUlts FOR THE U.S. SENATE AND U.S. HOUSE OF REPRESENTATIVES (2003), at http://www.fec.gov/ pubrec/fe2002/tcontents.htm (last visited Sept. 20, 2004) (listing 2002 election results by state, including each candidate's percentage of the vote).

${ }^{140}$ Hirsch, supra note 139, at 182 \& n.13; see also CQ'S POLITICS IN AMERICA 2004: THE 108TH CONGRESs (David Hawkings \& Brian Nutting eds., 2003) [hereinafter CQ's POLITICS] (providing election results for each member of Congress); MICHAEL Barone \& Richard E. Cohen, The Almanac of American Politics 2004 (2003) (same); Clerk OF THE HOUSE OF Representatives, Statistics OF THE CONGRESSIONAL Election OF NOVEMBER 5, 2002 (2003) (same). As a result, despite reapportionment and redistricting, only fifty-four of the 435 House members of the 107 th Congress did not return to the 108th, a mere 12.4\%. Hirsch, supra, at 183 tbl.1. 
tions, only thirty-eight districts nationwide were won with less than $55 \%$ of the major-party vote. ${ }^{141}$

We can further contrast the noncompetitiveness of House elections, which are based on gerrymandered districts, with elections the same day for state governors and U.S. Senators, both of whom are elected statewide and hence without any opportunity for gerrymandering to affect their elections: while one of twelve House elections was decided by ten percentage points or less, about half of all gubernatorial and U.S. Senate elections were within that margin. ${ }^{142}$

Perhaps not a single state demonstrates this so well as California, where voters rebelled en masse against the political status quo in 2003 to displace an elected governor by recall and to vote in an ostensibly more politically independent governor, Arnold Schwarzenegger. In the 2002 congressional elections, not a single challenger in the general election received over $40 \%$ of the vote. ${ }^{143}$ In other words, every single incumbent won by landslide margins.

The same process reproduces itself at the state legislative level. For example, in Florida-the narrowly divided state that swung the balance in the 2000 presidential election and is generally considered a battleground state in 2004-eleven of the twenty-two state senators up for reelection in 2004 face no opponent, and three more face no challenger from the other major party. ${ }^{144}$ The result is that even appreciable shifts in popular sentiment, as with displeasure over incumbent performance, finds little electoral manifestation. Dan Ortiz well captures one of the consequences of noncompetitive elections:

A national swing of five percent in voter opinion-a sea change in most elections-will change very few seats in the current House of Representatives. Gerrymandering thus creates a kind of inertia that arrests the House's dynamic process. It makes it less certain that votes in the chamber will reflect shifts in popular opinion, and thus frustrates change and creates undemocratic slippage between the people and their government. $^{145}$

${ }^{141}$ See CQ's Politics, supra note 140 (reporting the percentage of the popular vote garnered by each member of Congress elected in 2002).

${ }^{142}$ Hirsch, supra note 139, at 183.

${ }^{143}$ Id. at 182.

${ }^{144}$ See John Kennedy, Deadline Defines Outlook for Fall: Incumbent Power Chills Challengers, ORLANDO SENTINEL, July 17, 2004, at B1 (discussing the "trend toward legislative walkovers").

${ }^{145}$ Ortiz, supra note 139 , at 487. 
One way of thinking about this in terms of the constitutional structure of representation is that in the original Constitution, the Senate was picked by the state legislatures ${ }^{146}$ and the House was chosen by "the people," ${ }^{147}$ but that after a process of amendment ${ }^{148}$ and political adaptation, the houses have been inverted: now, the people pick the Senate and the state legislatures, through gerrymandering, pick the House.

A further harm plays itself out in the legislative arena among those elected in noncompetitive elections:

Left behind in the "sweetheart gerrymander" are the droves of median voters increasingly estranged from the polarized parties. Left behind as well are the incentives to provide representation to the community as a whole....

... The result is not only less electoral accountability but also more fractiousness in government and more difficulty in forming legislative coalitions across party lines. ${ }^{149}$

Noncompetitive elections threaten both the legitimacy and the vitality of democratic governance. Our aim here, however, is not so much to chronicle the real world harms of the gerrymander as to place the Court's doctrinal quagmire in perspective. Nor is our claim that an electoral system requires every district to be competitive. There will always be Berkeley and Orange County, or their equivalents. It would take a radical gerrymander to carve up stable and politically homogeneous areas in order to bring them to a contested balance between the major parties. The normal distribution of populations across 435 congressional districts will yield a range of districts, from those that are highly competitive and will likely elect centrist candidates or swing from election to election between the two major parties, to those that are more politically homogeneous and will gravitate toward the poles of the political spectrum. The perverse consequence of the incumbent gerrymander is that it skews the distribution politically by driving the center out of elected office at the legislative level. $^{15}$

${ }^{146}$ U.S. CONST. art. I, $\$ 3$.

${ }^{147}$ U.S. CONST. art. I, $\S 2$.

148 See U.S. CONST. amend. XVII (requiring popular election of senators)

${ }^{149}$ Samuel Issacharoff, Gerrymandering and Political Cartels, 116 HARV. L. REV. 593, 628-29 (2002).

${ }^{150}$ For a fuller explication of this point, see Samuel Issacharoff, Collateral Damage: The Endangered Center in American Politics, 46 WM. \& MARY L. REV. (forthcoming 2004). 
Instead our goal is twofold. In the first instance, we suggested that the Court's approach to fend off the direct challenge to the partisan gerrymander is unlikely to succeed on its own terms; challenges will be recast along other avenues of potential legal redress. We now turn to a further paradox of the Court's partisan gerrymandering jurisprudence. The efforts to cabin the types of claims that may be brought as challenges to partisan gerrymanders may perversely grant constitutional protection to the most systematic abuses of the redistricting process.

Of most concern to us is the potential to further misdirect legal challenge to gerrymandering into the mold of individual rights, even if now denominated "representational rights" to accommodate Justice Kennedy's First Amendment aperture. Already there are formidable barriers to challenging the consequences of gerrymandering. Standing doctrine is at times a significant hurdle since the consequence of the bipartisan or sweetheart gerrymander is to pack districts with partisans of the incumbent, thereby allowing a larger percentage of voters the opportunity to vote for the winning candidate. To the extent that the harm in gerrymandering is seen through the prism of individual rights claims, or, as Justice Stevens would have it, as claims limited to individual districts, ${ }^{151}$ what exactly do voters have to complain about? No voter could possibly be heard to have a claimed right to vote for the winning candidate. And even if this were the claim, gerrymandered districts offer greater numbers of voters such an opportunity. And no claim of systemic harm could possibly be advanced from the vantage point of one district.

The harm from the rights approach is that it pulls the Court even further from recognizing why its post-Bandemer jurisprudence failed. The root problem was ultimately the doomed effort to force the harm from gerrymandering into the blind alley of discrimination law. To begin with, as we set out earlier, the major parties are ill served by the comparison to Carolene Products minorities. As Daniel Lowenstein summarized this point in the context of redistricting, "the major parties are grown-ups who, generally speaking, can be expected to take care of themselves." ${ }^{152}$ Second, the rights approach directs litigants to

${ }^{151}$ See Vieth v. Jubelirer, 124 S. Ct. 1769, 1805 (2004) (Stevens, J., dissenting) (stating that "[b]ecause [United States v. Hays, 515 U.S. 737 (1995),] has altered the standing rules for gerrymandering claims-and because, in my view, racial and political gerrymanders are species of the same constitutional concern-the Hays standing rule requires dismissal of the statewide claim").

${ }^{152}$ Daniel Hays Lowenstein, Associational Rights of Major Political Parties: A Skeptical 
try to quantify the expected returns to each party so as to measure precisely the extent to which they had suffered discrimination. Nowhere is this more evident than in the actual litigation of Vieth, where the plaintiffs found themselves in the unenviable position of resting their constitutional challenge on an ornate statistical model that failed to predict fully the outcome of even the next election in Pennsylvania. ${ }^{153}$

Yet there are glimmers of hope emerging not just from Cox $v$. Larios, but from the sense that the Court is grasping for a broader theory of political legitimacy. For example, in the Court's most recent campaign finance decision, McConnell v. FEC, ${ }^{154}$ Justice Scalia questioned whether the Court's posture of deference to the political process could be justified when it was the accountability of the process itself that was in question. He argued that constitutional skepticism should be triggered precisely by the fact that incumbent political officials had drafted the finance limitations and "the present legislation targets for prohibition certain categories of campaign speech that are particularly harmful to incumbents." ${ }^{155}$ Of course, Justice Scalia would take this insight only so far and, in the seemingly parallel context of Vieth $v$. Jubelirer, found claims of incumbent entrenching behavior nonjusticiable.

In somewhat similar fashion, Justice Breyer in Vieth itself tried to ground the constitutionality of gerrymandering in a broader sense of democratic accountability:

$[\mathrm{O}]$ ne should begin by asking why single-member electoral districts are the norm, why the Constitution does not insist that the membership of legislatures better reflect different political views held by different groups of voters. History, of course, is part of the answer, but it does not tell the entire story. The answer also lies in the fact that a singlemember-district system helps to assure certain democratic objectives better than many "more representative" (i.e., proportional) electoral sys-

Inquiry, 71 TEX. L. REV. 1741, 1790 (1993).

${ }^{153}$ Contrary to expectations, the Democrats managed to carry one district that had been thought safely gerrymandered for Republicans. See Stephen K. Medvic \& Matthew M. Schousen, When Incumbents Clash, Fundamentals Matter: Pennsylvania Seventeen, in THE LAST HurRaH?: SOFT MONEY AND IsSUE AdVOCACY IN THE 2002 CONGRESSIONAL ELECTIONS 225, 233 (David B. Magleby \& J. Quin Monson eds., 2004) (explaining that the presumptively safe Republican lost because he was "a candidate rusty from years of easy re-election wins and out of touch with changing constituencies" and because of problems with his campaign team that produced "a strategy that careened futilely from one tack to another" (internal quotation marks and citations omitted)).

${ }_{154} 540$ U.S. 93, 124 S. Ct. 619 (2003).

${ }^{155}$ Id. at 721 (Scalia, J., concurring in part and dissenting in part). 
tems. Of course, single-member districts mean that only parties with candidates who finish "first past the post" will elect legislators. That fact means in turn that a party with a bare majority of votes or even a plurality of votes will often obtain a large legislative majority, perhaps freezing out smaller parties. But single-member districts thereby diminish the need for coalition governments. And that fact makes it easier for voters to identify which party is responsible for government decisionmaking (and which rascals to throw out), while simultaneously providing greater legislative stability. ... This is not to say that single-member districts are preferable; it is simply to say that single-member-district systems and more-directly-representational systems reflect different conclusions about the proper balance of different elements of a workable democratic government.

For Justice Breyer as well, grounding the gerrymandering problem in democratic accountability only goes so far. Despite attentiveness to the capacity to "throw the rascals out," he nonetheless allows that politicians must be given special latitude in crafting district lines because "political considerations will likely play an important, and proper, role in the drawing of district boundaries."157

Our aim here is not to be prescriptive and to announce a roadmap of where the Court must go. ${ }^{158}$ Rather, it is to highlight that Vieth, together with Larios, shows that the Court has followed the missteps of Bandemer to their ultimate resting point. Neither refinement of the statistical measures offered in Vieth nor recasting the underlying difficulties in the redistricting context as a matter of vaguely conceptualized "representational rights" under the First Amendment offers much hope for the future. And yet, something is seriously amiss in this area of our democratic politics.

\section{CONCLUSION}

In Colegrove v. Green, ${ }^{159}$ Justice Frankfurter explained the Court's refusal to address the constitutionality of an Illinois congressional district map that systematically undervalued the voting strength of the

${ }^{156}$ Vieth, 124 S. Ct. at 1823 (Breyer, J., dissenting).

${ }^{157} \mathrm{Id}$.

${ }^{158}$ We have made some efforts in the past to do just this. For example, one of us has proposed creating a constitutional presumption against any redistricting practice entrusted to partisan political officials. Issacharoff, supra note 149, at 601. Thus far, that approach has intrigued only Justices Souter and Ginsburg. See Vieth, 124 S. Ct. at 1819 n.5 (Souter, J., dissenting) ("The analogy to antitrust is an intriguing one that may prove fruitful, though I do not embrace it at this point out of caution about a wholesale conceptual transfer from economics to politics.").

159328 U.S. 549 (1946). 
state's urban and suburban populations by declaring that the plaintiffs' suit challenged "not a private wrong, but a wrong suffered by Illinois as a polity." ${ }^{160}$ By contrast, in Reynolds v. Sims, ${ }^{161}$ Chief Justice Warren acknowledged that courts exist to adjudicate claims of individual rights, rather than governmental structure, but declared that "the rights allegedly impaired" by malapportionment "are individual and personal in nature." ${ }^{162}$ And in Lucas v. Forty-Fourth General Assembly, ${ }^{163}$ one of the companion cases to Reynolds, the Court went so far as to insist that the ostensibly majority-protecting principle of one person, one vote could not be overridden even by a contemporary popular majority. ${ }^{164}$

Ironically, both Justice Frankfurter and Chief Justice Warren were half right. Justice Frankfurter was right that claims of malapportionment are really not individual rights claims; they are claims about governmental structure. Chief Justice Warren was right that courts must adjudicate these claims; they are especially appropriate issues for judicial review. Forty years of doctrinal development have failed, however, to accommodate this central point. Thus, the Court's gerrymandering jurisprudence channels cases into claims of individual rights, when they are really about issues of democratic governance and the allocation of power among groups. Unfortunately, the doctrinal moorings of Bandemer and potentially restrictive standing rules serve to reinforce the attention to matters of individual rights and discrimination, and they miss problems that cut deeper into the core of democratic selfgovernance. If, as Justice Scalia put it, Davis v. Bandemer "set [courts] wandering in the wilderness for 18 years," ${ }^{165}$ it's hard to see Vieth $v . J u$ belirer and Cox v. Larios as doing anything other than consigning us to another generation of hacking our way through the political thicket.

${ }^{160}$ Id. at 552 .

161377 U.S. 533 (1964).

${ }^{162} I d$. at 561 .

163377 U.S. 713 (1964).

${ }^{164}$ See id. at 736 ("An individual's constitutionally protected right to cast an equally weighted vote cannot be denied even by a majority of a State's electorate, if the apportionment scheme adopted by the voters fails to measure up to the requirements of the Equal Protection Clause.").

${ }^{165}$ Vieth, 124 S. Ct. at 1791. 